Federal Reserve Bank of Minneapolis

Sticky Prices and

Monetary Policy Shocks (p. 2)

Mark Bils

Peter J. Klenow

Oleksiy Kryvtsov

Measuring Consumption Growth: The Impact of New and Better

Products (p. 10)

Peter J. Klenow

2002 Contents (p. 24)

2002 Staff Reports (p. 25) 
Federal Reserve Bank of Minneapolis

\section{Quarterly Review vol. 27, No.1}

ISSN 0271-5287

This publication primarily presents economic research aimed at improving policymaking by the Federal Reserve System and other governmental authorities.

Any views expressed herein are those of the authors and not necessarily those of the Federal Reserve Bank of Minneapolis or the Federal Reserve System.

Editor: Arthur J. Rolnick

Associate Editors: Patrick J. Kehoe, Warren E. Weber

Economic Advisory Board: V. V. Chari, Thomas J. Holmes, Christopher Phelan, James A. Schmitz, Jr.

Managing Editor: Kathleen S. Rolfe

Article Editors: Kathleen S. Rolfe, Jenni C. Schoppers

Production Editor: Jenni C. Schoppers

Designer: Phil Swenson

Typesetter: Mary E. Anomalay

Circulation Assistant: Robbie Egge

The Quarterly Review is published by the Research Department of the Federal Reserve Bank of Minneapolis. Subscriptions are available free of charge.

Quarterly Review articles that are reprints or revisions of papers published elsewhere may not be reprinted without the written permission of the original publisher. All other Quarterly Review articles may be reprinted without charge. If you reprint an article, please fully credit the source - the Minneapolis Federal Reserve Bank as well as the Quarterly Review - and include with the reprint a version of the standard Federal Reserve disclaimer (italicized above). Also, please send one copy of any publication that includes a reprint to the Minneapolis Fed Research Department.

Electronic files of Quarterly Review articles are available through the Minneapolis Fed's home page on the World Wide Web: http://www.minneapolisfed.org.
Comments and questions about the Quarterly Review may be sent to

Quarterly Review

Research Department

Federal Reserve Bank of Minneapolis

P. O. Box 291

Minneapolis, Minnesota 55480-0291

(Phone 612-204-6455 / Fax 612-204-5515).

Subscription requests may also be sent to the circulation assistant at robbie.egge@mpls.frb.org; editorial comments and questions, to the managing editor at ksr@res.mpls.frb.fed.us. 


\title{
Measuring Consumption Growth: The Impact of New and Better Products*
}

\author{
Peter J. Klenow \\ Senior Economist \\ Research Department \\ Federal Reserve Bank of Minneapolis \\ and Faculty Research Fellow \\ National Bureau of Economic Research
}

Official government data put growth in real (that is, inflation-adjusted) consumption per capita at 2.4 percent per year in the United States from 1960 to $2000 .{ }^{1}$ If consumers bought a fixed set of constant-quality goods and services over time, then measuring consumption would require simply counting the number of telephones, televisions, cars, haircuts, house cleanings, insurance policies, and so on bought each year. But goods and services do change over time. Much of consumption growth involves new varieties of goods (for example, cellular phones, cable TV subscriptions, new prescription drugs, minivans) and higher quality versions of existing goods (for example, cell phones with clearer reception, heart attack treatments that extend lives longer, and cars that are more durable). ${ }^{2}$ The benefits of such new and better products are difficult to measure, and official data may understate the growth in consumer spending by not fully taking these benefits into account.

Just how much growth comes from new and better products is an active area of research. The Boskin Commission (U.S. Congress 1996) concluded that properly incorporating advances in variety and quality would add 0.6 of a percentage point to annual consumption growth and that other corrections would add another 0.3 of a percentage point. According to the commission's estimates, the benefits of new goods represented at least 18 percent of the consumption growth between 1960 and 2000 ( 0.6 of a percentage point of the true 3.3 percent growth rate). The contribution of new goods was likely to be much greater than this. The 2.4 percent official growth rate already included some of the benefits of new goods. And the Boskin Commission stressed only the benefits of declining prices for new varieties after they are introduced. The commission largely neglected the benefits of access to new varieties at their initial prices (for example, new prescription drugs or Internet services).

The purpose of this study is to describe why measuring real consumption growth is difficult in the presence of a changing set of goods and what improvements have recently been made in the U.S. government's methodology for measuring real consumption growth. Accurate measurement of real consumption is important for addressing a host of questions: How does the standard of living today compare to that of previous generations? Are living standards improving at a faster rate, signifying a New Economy? Answers to these questions inform policy decisions about intergenerational transfers, about intellectual property

*The author is grateful to Mark Bils, Tom Holmes, Kathy Rolfe, Art Rolnick, and Jim Schmitz for useful comments.

${ }^{1}$ The data used to calculate this growth rate are from the U.S. Bureau of Economic Analysis (chain-weighted consumption in 1960 and 2000, both expressed in 1996 dollars) and the U.S. Bureau of the Census (the population in July of 1960 and July of 2000).

${ }^{2}$ Here and elsewhere I refer to goods as shorthand for goods and services. And hereafter I will often use new goods to mean both new varieties and better versions of existing varieties. 
rights, and about the optimal inflation rate. Social Security benefits and the U.S. tax code are currently indexed to estimates of the cost of living. And price stability is a main objective of monetary policy. If the goal is stable prices with variety and quality taken into account, then true price stability might be associated with, for example, 0.6 percent annual increase in the price of consumer goods (using the Boskin Commission's estimate of omitted growth in variety and quality).

\section{Defining Consumption Growth ... .}

When policymakers and others attempt to measure consumption, their ultimate aim is to measure the level of satisfaction, or utility, that consumers get from the goods they buy. As a result, measurement must take account of more than just the number of goods consumers have purchased. Consumers get utility from the quantity, variety, and quality of goods they consume. One can define growth in real consumption as

$$
\% \Delta c=(1+\lambda)(\% \Delta N+\% \Delta Q)+\% \Delta q
$$

where $c$ is real consumption, $N$ is the number of distinct varieties of goods bought, $Q$ is the quality of those goods, and $q$ is the number of units consumed of each variety. ${ }^{3}$ The parameter $\lambda$ governs the gains from enjoying more variety and a higher level of quality compared to the gain from buying a greater quantity. As I will discuss at length, $\lambda>0$ appears to be realistic in that people choose to spend additional income disproportionately on variety and quality. Think of food, housing, cars, TV, and medical care.

A richer specification than that in equation (1) would distinguish sets of goods that are closer substitutes (for example, cell phones vs. land line phones or SUVs vs. minivans) or even complements (for example, gasoline and cars or perishables and refrigerators). Specification (1) also assumes that all consumers have the same preferences. In reality, of course, spending patterns differ by age, gender, and so on. In fact, differences in preferences across individuals may be a reason variety is valuable to consumers. Different consumers may favor particular products (say, particular types of breakfast cereal or particular TV shows). If so, greater variety allows individual consumers to get closer to their optimal mix of characteristics (say, in toothpaste, ballpoint pens, clothes, or furniture). Petrin (2002) demonstrates this with regard to car buyers. He estimates that minivan buyers moved closer to their ideal car purchase after the introduction of minivans.

\section{... And Measuring lt}

In order to see more clearly the components of real consumption growth, one can rearrange expression (1) as follows:

$$
\% \Delta c=\overbrace{\text { Easy to Measure }}^{\begin{array}{c}
\text { Government } \\
\text { Tries to Measure }
\end{array}}+\overbrace{\text { Hard to Measure }}^{\begin{array}{c}
\text { Does Not } \\
\text { Try to Measure }
\end{array}} .
$$

\section{Adjusting for Changes in Prices . . .}

To remove the effects of price changes on dollar growth in consumer spending and so measure real consumption growth, the U.S. Commerce Department's Bureau of Economic Analysis (BEA) subtracts growth in a price index from growth in current-dollar spending. ${ }^{4}$ The BEA obtains estimates of nominal consumption from U.S. Census Bureau surveys of retail trade, manufacturing, and service establishments. These surveys are designed to capture all sales to consumers, regardless of how new the item. As a result, over long periods such as 1960-2000, the BEA nominal consumption growth rates should capture spending on new and higher quality varieties, as in the "easy to measure" component of equation (2). The main difficulties for the BEA are in measuring quality growth and capturing the benefits of increased variety and quality, that is, the "hard to measure" component of (2).

For price indexes in its calculations, the BEA predominantly uses consumer price indexes (CPIs) constructed by the U.S. Labor Department's Bureau of Labor Statistics (BLS). To construct the CPIs, the BLS collects prices on about 80,000 goods every month (U.S. Department of Labor 1997). Prices for this basket of goods are collected from around 23,000 outlets (supermarkets, department stores, gasoline stations, hospitals, and so on), 50,000 landlords and tenants, and 20,000 owner-occupants across

\footnotetext{
${ }^{3}$ This expression can be derived from the utility function$$
u_{t}=\sum_{i=1}^{N_{t}} Q_{i t} q_{i t}^{(\sigma-1) / \sigma}
$$

and the assumption that prices and qualities are the same for all varieties. Here $\sigma$ is the elasticity of substitution between varieties and $\lambda=1 /(\sigma-1)$. In $(1), \% \Delta$ refers to the percentage growth rate.

${ }^{4}$ To arrive at aggregate real consumption growth, the BEA chain-weights the real growth rates of around 200 consumption categories. See U.S. Department of Commerce 2001 for a description of the BEA's chain-weighting methodology.
} 
Table 1

How the BLS Currently Adjusts Consumer Prices for Quality Growth

\begin{tabular}{llll}
\hline Type of Method & Name of Method & When Method Applied & Items Affected \\
\hline Passive & Matched-Model & $\begin{array}{l}\text { All times other than } \\
\text { sample rotations and } \\
\text { item substitutions }\end{array}$ & All items \\
& Overlap & $\begin{array}{l}\text { Sample rotations } \\
\text { Link }\end{array}$ & All items \\
& Item substitutions & Most items \\
Hedonics & Item substitutions & $\begin{array}{l}\text { Apparel, PCs, TVs, } \\
\text { microwaves, refrigerators, } \\
\text { freezers, clothes washers } \\
\text { and dryers }\end{array}$ \\
& Manufacturer & Item substitutions & Vehicles and gasoline \\
\hline
\end{tabular}

Source: U.S. Department of Labor, Bureau of Labor Statistics (BLS)

more than 80 urban areas. The outlets are sampled probabilistically based on household point-of-purchase surveys, and the items within each outlet are sampled according to estimates of their relative sales. The BLS periodically rotates its samples of outlets and items to try to keep pace with changing household buying patterns. Unfortunately, the BLS does not use sample rotation to try to measure the change in the number of distinct varieties of goods, $\% \Delta N$. Combined with an estimate of the parameter $\lambda$, such data could be used to estimate the value of changing variety, a hard-to-measure and currently unmeasured piece of (2).

\section{... And in Quality}

The BLS aims to measure growth in prices with quality growth taken into account. That is, it tries to net out quality increases to arrive at growth in quality-adjusted prices. If the BLS succeeds, then the BEA measure of real consumption growth fully incorporates quality growth. To adjust for quality growth, the BLS uses both passive and active methods. Its passive matched-model and overlap methods attempt to measure price changes only for goods of unchanging quality. Its active methods - primarily hedonics, but also manufacturer cost estimates in the case of cars - try to measure differences in quality between new and old goods. Table 1 provides an overview of when and where the BLS currently applies these methods.

The matched-model method strives to measure the price of the same item from month to month. When this method succeeds, only goods of identical quality are compared across time. To implement this method, field agents collecting price quotes use detailed checklists of item attributes to try to ensure that they are pricing the same items in consecutive months.

To illustrate how the matched-model method works, suppose a particular Toyota Camry is included among the items in the CPI, along with a more expensive, higher quality Lexus car model. Suppose further that the attributes of these car models remain unchanged over a certain period, but that households become richer, so that the number of units sold rises for the Lexus relative to the Camry. The BLS matched-model method never compares the prices of the Camry and Lexus. It compares only the prices of 
Camrys to Camrys and the prices of Lexuses to Lexuses. Since the Lexus is more expensive than the Camry, the shift in market shares is associated with rising consumer spending on cars. Because the shift does not affect the BLS price index for cars, the higher spending contributes to higher BEA real consumption. No new varieties or greater quantities of cars are involved, so such growth represents measured quality growth rather than variety growth or quantity growth. As this example illustrates, the matchedmodel method is a passive way of allowing quality growth to flow into real consumption growth.

To extend the example, suppose a new car model (say, a Saturn) arrives on the market and wins market share at the expense of less expensive, lower quality models. The new Saturn will not be immediately incorporated into the CPI basket. Still, in the matched-model method, the higher consumer spending from the switch to Saturns shows up as real consumption growth because the BLS keeps tracking the prices of the (now less popular) lower quality models. When the new Saturn model is later rotated into BLS samples at the expense of lesser selling models, the BLS does not register the difference in their prices as inflation. The BLS instead uses the overlap method, collecting prices on incoming and outgoing items for an overlapping month. In the overlap month the BLS registers inflation as that on the outgoing item. In subsequent months, it registers inflation as that on the incoming item. In using this overlap method, the BLS implicitly assumes that price differences equal quality differences for incoming versus outgoing items. The BLS is passively measuring quality growth as the price difference between the old and new items in the sample.

Unfortunately, the matched-model and overlap methods are not always feasible because items are frequently discontinued by the outlets in between BLS sample rotations. Moulton and Moses (1997, p. 323) report that around 30 percent of items that are not scheduled for BLS sample rotation are discontinued by retailers in a typical year. For these items, the BLS is forced to compare distinct items and sift quality-adjusted price differences from raw price differences. When an outlet discontinues an item, field agents search for the closest substitute at the outlet. Table 2 presents monthly item substitution rates over 1995-97 for different categories of consumption, tabulated from unpublished BLS data. ${ }^{5}$ As Table 2 shows, forced item substitutions were more common for goods than for services during this period. They were also more common for apparel, as one might expect with changing styles.
Table 2

The Frequency of Forced Item Substitutions in the CPI

Monthly Item Substitution Rate, 1995-97

\begin{tabular}{|c|c|c|c|}
\hline Category* & All Substitutions & $\begin{array}{l}\text { Noncomparable } \\
\text { Substitutions }\end{array}$ & $\begin{array}{c}\text { Weight in } \\
\text { Dec. } 2000 \text { CPI }\end{array}$ \\
\hline All Items & $3.1 \%$ & $1.5 \%$ & $69.8 \%$ \\
\hline Durable Goods & 8.4 & 5.6 & 10.6 \\
\hline Nondurable Goods & 3.0 & 1.2 & 31.3 \\
\hline Services & 1.6 & .5 & 27.9 \\
\hline Food & 1.7 & .9 & 16.2 \\
\hline Home Furnishings & 2.2 & .9 & 9.7 \\
\hline Apparel & 9.2 & 3.1 & 4.5 \\
\hline Transportation & 5.3 & 3.0 & 17.6 \\
\hline Medical Care & 1.2 & .9 & 5.8 \\
\hline Entertainment & 2.8 & 1.3 & 5.9 \\
\hline Other & 1.6 & .6 & 10.1 \\
\hline
\end{tabular}

"Shelter ( 30.2 percent of the Dec. $2000 \mathrm{CPI}$ ) is excluded from all calculations. Durables, nondurables, and services otherwise coincide with U.S. national income and product account definitions. The categories food, housing (home furnishings above), apparel, transportation, medical care, entertainment, and other are BLS major groups for the CPI. Source: U.S. Department of Labor, Bureau of Labor Statistics (BLS)

The BLS compares the attributes of the replacement item to those of the discontinued item and classifies the replacement as either comparable or noncomparable to the discontinued item. Table 2 provides noncomparable substitution rates alongside the overall substitution rates. Noncomparable substitutions were ten times more common for durables than for services. The BLS deemed 48 percent of substitutions (1.5 percent of monthly price quotes) noncomparable over 1995-97. As noted, forced substitutions occur for around 30 percent of items in a typical year. This is very close to what one would find if all items had an equal and constant 3 percent monthly probability of being replaced. If all items had a constant 1.5 percent monthly noncomparable substitution rate, then 17 percent of items

\footnotetext{
${ }^{5}$ The BLS prices food and energy items monthly in all cities in its sample. In the five largest cities the BLS prices all items monthly. The BLS collects other prices bimonthly. Table 2 gives the monthly substitution rates implied by the mix of monthly and bimonthly substitution rates.
} 
would be replaced with products of dissimilar quality in a typical year. ${ }^{6}$

The price of a comparable substitute enters the CPI without adjustment because the BLS deems the new item as essentially the same as the old item. In contrast, a noncomparable substitute enters the CPI with quality adjustments. In some categories, the BLS makes active quality adjustments, for example, using hedonic estimates. ${ }^{7}$ Over 1995-97, direct quality adjustments were made for 19 percent of all item substitutions. They were most common for trucks, cars, and men's and women's suits. For other noncomparable substitutions (29 percent of all substitutions), the BLS adjusted for quality passively, scaling the replacement's price so that the change in quality-adjusted price matched the inflation rate of items not substituted within the same category. This link method of quality adjustment usually involved scaling down the replacement item's price, with the replacement item inferred to be of higher quality than the discontinued item.

How large are BLS quality adjustments? For 1995, Moulton and Moses (1997, p. 341) report that quality adjustments amounted to 1.76 percentage points. CPI inflation was 2.16 percent in that year, so it would have been 3.92 percent without the quality adjustments. These are the active quality adjustments the BLS made for noncomparable item substitutions. In addition to these, the BLS made passive quality adjustments using the matched-model method and, during sample rotations, the overlap method.

To infer combined quality adjustments, at item substitutions and at other times, one needs to compare the average unit prices paid by consumers to the BLS price index. In Bils and Klenow 2001b, we estimate average unit prices paid for 66 durable goods over 1980-96 from the consumer expenditure survey (CES) conducted by the BLS. For these goods, which represented about 12 percent of the CPI, average unit prices rose 1.46 percentage points faster than BLS price indexes over 1980-96 (Bils and Klenow 2001b, p. 1020). This is smaller than the Moulton and Moses (1997) estimate of 1.76 percentage points of active quality adjustments alone in 1995, suggesting that 1995 may have been a year of unusually large active quality adjustments. Another possibility is that active quality adjustments were smaller for the 66 durable goods examined than for the average item in the CPI, but this seems unlikely given the high rate of product turnover for durables relative to other items. Although these estimates are sketchy, they underscore the possibility that most of the official 2.4 percent annual measured growth in real con- sumption per capita over 1960-2000 came from growth in quality.

\section{Critiquing U.S. Methodology ... .}

The Boskin Commission (U.S. Congress 1996) concluded that the CPI overstated inflation in the cost of living and recommended a number of changes to BLS procedures. The commission estimated the upward bias in CPI inflation at 1.1 percentage points per year, with a range of plausible values between 0.8 and 1.6 percentage points. Usefully, the commission subdivided its bias estimate into component sources, reproduced here in Table 3.

\section{Sources of Bias}

\section{Substitution Between Existing Products}

Substitution bias arises when households shift away from items with quickly rising prices toward items with slowly rising (or falling) prices. Personal computers (PCs) are a clear example: their quality-adjusted prices have fallen for the last two decades, and consumers have responded by buying so many more computers that total computer spending has risen. Historically, the quantity weights on various items in the CPI have been fixed for a decade at a time, as if consumers had no ability to switch toward items with low or negative inflation. This overstated increases in the cost of maintaining a given standard of living. The Boskin Commission estimated that upper-level substitution - substitution between 200 or so categories (or types of goods and services), such as prescription drugs, new cars, cable TV subscriptions, and dental servicescontributed 0.15 of a percentage point upward bias per year to CPI inflation. The commission estimated that lower-level substitution - substitution between items within each upper-level category, for example, different types of drugs or different car models-was responsible for 0.25 of a percentage point of upward bias per year.

Only one of these substitution biases also affects (in the opposite direction) the BEA's estimate of the real growth

\footnotetext{
${ }^{6}$ The noncomparable substitution rate could be viewed as an estimate of the exit rate of goods and services. If the BLS also tabulated gross entry of new items at sample rotations, then at these points the BLS could measure the net entry rate, that is, $\% \Delta N_{r}$ As mentioned above, this could be combined with an estimate of the substitutability of different varieties to measure the welfare gain from rising variety as appears in equation (2).

${ }^{7}$ Hedonics involve regressing item prices on item attributes for a sample of items with differing attributes. (If items are pooled across time, then a different price intercept is included for each period.) The estimated coefficients are applied to any difference in attributes to determine the quality difference (in price units) between a replacement item and a discontinued item.
} 
Table 3

Boskin Commission Estimates of Bias in the CPI

\begin{tabular}{lc}
\hline Source of Bias & $\begin{array}{c}\text { Upward Annual Bias } \\
\text { (Percentage Points) }\end{array}$ \\
\hline Upper-Level Substitution & .15 \\
Lower-Level Substitution & .25 \\
New Outlets & .10 \\
New and Better Products & .60 \\
All Sources & $\frac{.10}{}$ \\
\hline
\end{tabular}

Source: U.S. Congress 1996

rate of consumption. When calculating the real growth rate of consumption, the BEA does not subtract the growth rate of the overall CPI from the growth rate of overall nominal consumption. Instead, the BEA uses upper-level CPIs to separately calculate the growth rate of real consumption for each upper-level category and then chainweights the upper-level real growth rates to arrive at an overall growth rate. For its chain weights, the BEA uses current and previous year consumer spending shares. For this reason, BEA estimates of real consumption growth are not subject to upper-level substitution bias. They are, however, subject to lower-level substitution bias. Lowerlevel substitution biases upward the category CPI inflation rates the BEA uses and, therefore, biases downward the BEA category real growth rates. Roughly speaking, each percentage point of upward bias in the CPI category inflation rates biases BEA real growth rates downward by 1 percentage point.

\section{New Outlets}

Another source of bias identified by the Boskin Commission was a shift by households toward shopping at new, large outlets that offer discount prices. Prime examples of this phenomenon are superstores such as Wal-Mart and membership warehouse clubs such as Costco. The BLS treats discount outlets as providing different items rather than less expensive items. The BLS position is that discount stores provide less service and sell in bulk (requiring greater household storage space). The Boskin Com- mission argued that the rising market share of superstores and warehouse clubs is evidence that their lower prices more than offset the inconveniences for their customers. Both Shapiro and Wilcox (1996) and the Boskin Commission estimated outlet bias to be around 0.1 of a percentage point per year.

\section{New Products}

The final and largest source of bias identified by the Boskin Commission was the introduction of new products, including higher quality versions of previously existing products. The commission put this bias at 0.6 of a percentage point per year. The commission provided separate estimates of quality change and new products bias for 27 categories of consumer spending and weighted them by category shares in the CPI to arrive at a weighted average of 0.6 of a percentage point. The commission cited uncertainty about this bias as the main contributor to its range of from 0.8 to 1.6 percentage points for overall CPI inflation bias.

The crux of the Boskin Commission's argument for bias involving new products is the notion of a product cycle. New products tend to enter the market at a high price and initially sell few units. Later their price falls and, if they are successful, their sales rise. Gort and Klepper (1982) present evidence of this phenomenon for 46 products, Irwin and I (1994) for many generations of computer memory chips, Hausman (1999) for cell phone prices and use charges, and Rohlfs (2001) for PCs, fax machines, and videocassette recorders (VCRs).

Chart 1 illustrates the classic product cycle. As shown, the fall in price occurs because the supply curve shifts rightward over time. The supply curve may do so because firms learn how to produce at lower cost or because competing firms enter the market or both. Although not captured by Chart 1 , other potential contributors to rising sales are intertemporal price discrimination, consumers learning about the new good, and an expanding network of users of the good. For evidence of the latter two effects, see the work of Berndt, Pindyck, and Azoulay (2000) on anti-ulcer drugs and my work with Goolsbee (2002) on home computers.

Based on the product cycle, the Boskin Commission recommended that the BLS more frequently update the items in the CPI basket. VCRs and PCs did not enter the basket until 1987 and cell phones and Internet service providers (ISPs) not until 1998. Just as important, these new items did not enter the basket at their full current weight in consumer spending. This was because the BLS rotated all 


\section{Chart 1}

\section{The Classic Product Cycle}

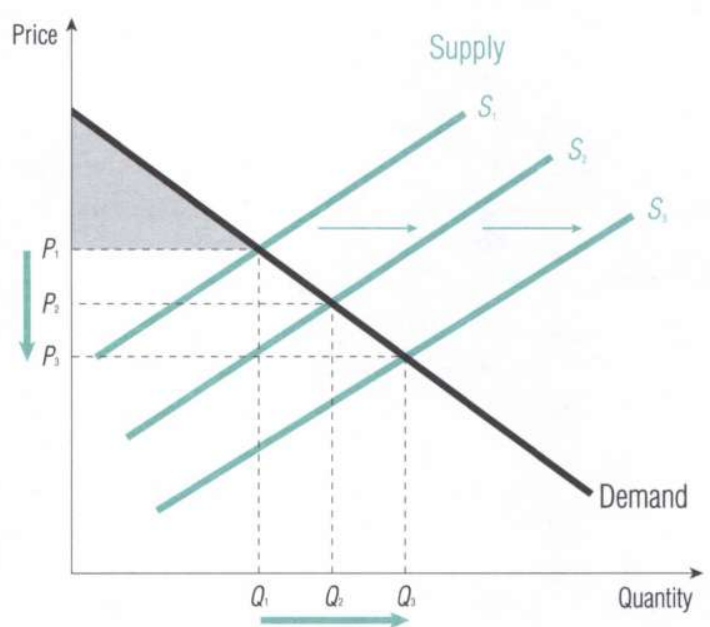

items in one-fifth of the cities every year (meaning a new item would take five years to be incorporated into all areas), because these new items did not fall into existing categories (and therefore required new categories to be created), and because the BLS updated upper-level spending weights only every ten years. In 2000 , the relative importance of PCs in the CPI stood at 0.078 percent, compared to their 0.378 percent share of consumption expenditures in BEA data. ${ }^{8}$

Putting too little weight on new products during their falling price phase can mean overstated CPI inflation and understated real consumption growth. In short, it can mean government statistics fail to incorporate some of the benefits of new products. Moreover, even instant inclusion of new products into the CPI would fail to capture all of the benefits of new products. ${ }^{9}$ The shaded triangle in the upper-left region of Chart 1 represents surplus enjoyed by initial buyers of new products. It highlights how some consumers value the new product more than they pay for it. The difference is a gain not captured in government statistics. Examples include pharmaceuticals and ISPs. Many new prescription drugs address conditions untreated by existing drugs. Many ISP subscribers would be willing to pay more if necessary for their home access to email

\section{Table 4}

The Contribution of Item Substitutions to CPI Inflation

\begin{tabular}{lccc}
\hline Category & Year & Substitution Rate & $\begin{array}{c}\text { Share of Inflation } \\
\text { Due to Substitutions }\end{array}$ \\
\hline All Items & 1983 & $3.9 \%$ & $61 \%$ \\
& 1984 & 4.0 & 96 \\
& 1995 & 3.9 & 50 \\
Nonapparel Items & 1983 & 2.6 & 20 \\
& 1984 & 2.7 & 34 \\
& 1995 & 3.2 & 31 \\
\hline
\end{tabular}

Source: Moulton and Moses 1997

and the Internet. This surplus is akin to the gain from variety described above in expression (2). As indicated in (2), neither the BEA nor the BLS attempts to incorporate this gain from new products.

The Boskin Commission also criticized the BLS's quality adjustment procedures. The commission argued that comparable substitutions often involved quality improvements such as greater picture quality for TVs, greater fuel efficiency for appliances, and greater durability for cars and consumer electronics. Regarding surveys of automakers, the commission pointed out that improvements in inputs (for example, more durable tires) need not raise manufacturer costs in the same proportion. As for passive quality adjustments, the commission challenged the assumption that quality-adjusted inflation is the same for substituted items as for items not substituted. The commission argued that substituted items are more likely to be in the mature phase of the product cycle and, hence, exhibit faster rates of true inflation. Finally, regarding sample

\footnotetext{
${ }^{8}$ The relative importance of software was 0.028 percent in the December $2000 \mathrm{CPI}$ versus 0.131 percent in 2000 consumption expenditures. CPI shares were obtained from www.bls.gov/cpihome; personal consumption expenditure shares were obtained from www.bea.gov.

${ }^{9}$ This point was not stressed by the Boskin Commission, except in its discussion of new varieties of fresh fruits and vegetables, new breakfast cereals, and the introduction of cell phones.
} 
rotations, the commission argued that new items must have lower quality-adjusted prices than old items in order to explain why market share is higher for the new items.

Moulton and Moses (1997) report that whereas item substitutions occurred for only about 4 percent of price quotes in 1983, 1984, and 1995 (the years studied), they accounted for 50 percent or more of overall CPI inflation in each of those years. (See Table 4.) One should probably exclude apparel from these calculations, however, because apparel items are typically marked down and replaced with full-priced items. The inflation associated with apparel turnover arguably reflects seasonal and fashion cycles rather than secular quality improvements. Table 4 shows that, even excluding apparel, substitutions accounted for a disproportionate amount of CPI inflation in the years studied. Excluding apparel, the 2.6-3.2 percent of price quotes involving item substitutions accounted for 20-34 percent of inflation. As Moulton and Moses point out, firms implement true price increases when they change item attributes. But another interpretation is that BLS procedures understate quality improvements at item substitutions.

\section{... And Improving It}

Table 5 shows that the Boskin Commission is not alone in estimating about 1 percentage point of upward bias in the CPI inflation rate. Lebow, Roberts and Stockton (1994) and Shapiro and Wilcox (1996) estimated similar rates of bias. Since the Boskin Commission, the BLS has implemented a number of changes to estimate quality growth better and to incorporate new products sooner. Table 6 lists some of these changes, as well as some important improvements that preceded the Boskin Commission.

In 1997 the BLS began pricing specific medical procedures rather than the overall cost of a doctor visit or a day in the hospital. This avoids registering price increases when more procedures are done per visit or per day in the hospital. However, this still does not capture improvements in the quality of a given procedure. As Cutler et al. (1998) show for heart attack treatments and Shapiro, Shapiro, and Wilcox (1999) show for cataract surgery, outcomes have improved dramatically on a number of dimensions.

The BLS expanded its use of hedonics to PCs in 1998, to TVs in 1999, and to microwave ovens, refrigerators, freezers, and clothes washers and dryers in 2000 . The combined importance of these items in the December 2000 CPI is modest ( 0.39 of a percentage point), but the importance of PCs is growing. The BLS is currently doing research on extending hedonics to college textbooks (the number of pages, hardcover vs. softcover, graphics),

\section{Table 5}

Estimates of Bias in CPI Inflation

and Real Consumption Growth

\begin{tabular}{lcc}
\hline & \multicolumn{2}{c}{ Percentage Points Per Year } \\
\cline { 2 - 3 } Source & CPI Inflation & $\begin{array}{c}\text { Real Consumption } \\
\text { Growth }\end{array}$ \\
\hline $\begin{array}{l}\text { Lebow, Roberts, } \\
\text { and Stockton (1994) }\end{array}$ & 1.0 & -.8 \\
$\begin{array}{l}\text { Boskin Commission } \\
\text { (U.S. Congress 1996) }\end{array}$ & 1.1 & -.9 \\
$\begin{array}{l}\text { Shapiro and Wilcox (1996) } \\
\text { Revised Boskin Commission } \\
\text { (U.S. Congress 2000) }\end{array}$ & 1.0 & -.8 \\
Lebow and Rudd (2001) & .6 & -.7 \\
\hline
\end{tabular}

VCRs, DVD players, camcorders, and audio products. The growing availability of scanner data may expand this list considerably in the future.

In 1998 the BLS began rotating certain items and outlets in all areas, rather than rotating all items and outlets in a given area. This allows the BLS to more frequently rotate items with rapid new product introduction and quality change and outlets with higher entry and exit rates. The BLS now rotates less frequently those items with low substitution rates and outlets with low turnover rates. The BLS also shortened the maximum time between rotation of any item or outlet from five to four years. Also in 1998, the BLS redefined upper-level categories to more easily accommodate new products.

In 1999 the BLS began applying a geometric mean formula to lower-level items. Instead of assuming constant quantities spent on a given item (as with arithmetic weights), geometric weights assume constant nominal spending shares on lower-level items. With geometric weighting, a 1 percentage point relative price increase is assumed to induce a 1 percentage point relative quantity decrease for an item within a category. ${ }^{10}$ The BLS esti-

\footnotetext{
${ }^{10}$ The BLS used three types of evidence to conclude that consumers substitute among lower-level items to this degree. First, it used supermarket scanner data on
} 
mates that moving from arithmetic to geometric weights will reduce CPI inflation by 0.2 of a percentage point per year on average. ${ }^{11}$

In 2002 the BLS began updating upper-level weights every other year. Weights are now based on consumer spending patterns from two to four years prior, compared to an average of nine years prior with the old updating schedule. Table 7 shows the CES years used to determine the CPI weights in various years. ${ }^{12}$ The BLS estimates that using more recent CES weights would have reduced $1988-97$ inflation by 0.17 of a percentage point per year. ${ }^{13}$

Taken together, the changes in BLS methodology since the Boskin Commission significantly shorten the lag between the time a product hits the market and the time it enters the CPI. The BLS also promises to more quickly ramp up a product's importance in the CPI to its weight in the marketplace. As a result, the BLS should capture more of the falling price phase of a new product's cycle. Based on these changes, one member of the Boskin Commission has more than halved his estimate of CPI inflation bias from 1.1 percentage points to 0.5 of a percentage point (Gordon 2000). A General Accounting Office (U.S. Congress 2000) survey of the other commission members found a more modest downward revision to around 0.8 of a percentage point of remaining bias per year. A recent study by Lebow and Rudd (2001) estimates only 0.6 of a percentage point of bias per year going forward. Table 5 , again, summarizes the various estimates and their implications for downward bias in the BEA's estimate of real consumption growth. As noted, upper-level substitution bias in the CPI does not apply to the BEA real growth rates because the BEA uses chain weights on upper-level categories. For this reason, the downward bias estimates for real consumption growth are $0.10-0.25$ of a percentage point lower than the estimates for upward CPI inflation bias.

\section{Recent Research}

New goods have the capacity to attract consumer expenditures away from existing goods. Table 8 illustrates this for some recent products over the last 20 years. Over this period, cable TV subscriptions fueled a broad increase in spending on television despite a relative decline in spending on television sets. People now spend considerably more on cable TV service than on TV sets. VCRs and movie rentals likewise spurred spending on movies, with such spending now almost three times greater than spending to see movies in theaters. Similarly, PCs drove growth in spending on home audio and video equipment, and cell phone services carried the telephone spending share higher. In the 20 years prior to the ascendance of these new items, their categories were flat or in decline. Similarly, new medical procedures and prescription drugs are a major force behind the soaring share of medical care spending (from 6.7 percent of all consumption in 1960 to 17.4 percent in 2000). And desire for variety and quality has boosted eating out at restaurants. Food away from home comprised 40.5 percent of all food spending in 2000 , up from 24.7 percent in $1960 .^{14}$

Expanding Table 8 to cover spending on all new goods, or even new medical procedures and drugs, would be a daunting task given currently available data. Without more data, it is hard to obtain a direct measure of the role of spending on new and better items in overall consumption growth. Even simple counts of the number of new products are hard to come by. An important exception is supermarkets, for which the Food Marketing Institute (2000) tracks the number of items available going back to 1978. It reports that the number of items carried by the average U.S. supermarket rose from 10,425 in 1978 to 40,333 in 2000, an annual growth rate of 6.7 percent. Several notes of caution are in order regarding this number. First, grocery store items need not be representative of all consumption. Second, many of the items introduced were new to supermarkets, but not new to consumers, as supermarkets introduced in-store bakeries ( 87 percent of supermarkets by 2000 ), delis ( 90 percent), and additional ready-

prices charged and quantities sold for a limited number of items. Second, it noted the extent to which consumers substitute among upper-level categories based on CES data. Shapiro and Wilcox (1997) and Bils and I (2001a) estimated the upper-level elasticity of substitution to be around 0.7 . One would expect even more substitution among lower-level items (for example, wheat bread vs. seven-grain bread) than among upperlevel categories (bread vs. milk). Third, the BLS surveyed the empirical literature on elasticities of substitution at the brand level.

${ }^{11}$ The BLS estimates that applying the geometric mean formula retroactively back to 1990 would lower the $1990-97$ inflation rate by 0.34 of a percentage point per year. It is BLS policy not to revise the official CPI.

${ }^{12}$ The BLS may eventually shorten the lag to one year. The CES sample was significantly expanded in 1999, so a single year's sample will be more reliable. The United Kingdom currently bases its retail price index weights on a family expenditure survey only one year prior.

${ }^{13}$ To more directly and fully address upper-level substitution bias, in 2002 the BLS began publishing a separate superlative (or chained) index, which uses current and lagged spending shares to weight the 200 or so upper-level categories. As additional data are processed on spending weights, the superlative index is revised. According to BLS forecasts, the superlative index will grow between 0.1 and 0.2 of a percentage point slower than the official CPI. Because the BEA already chain-weights upper-level categories, neither the BLS schedule for updating upper-level weights nor the BLS superlative index has any bearing on BEA measurement of real consumption growth.

${ }^{14}$ In Bils and Klenow 2001a, we find that price, income, and demographic shifts explain only a fraction of the trends mentioned in this paragraph. 
Table 6

Changes in CPI Methodology Related to New and Better Products

\begin{tabular}{|c|c|c|c|}
\hline Subject of Change & $\begin{array}{l}\text { Year } \\
\text { Change } \\
\text { Made }\end{array}$ & $\begin{array}{l}\% \text { of } \mathrm{CPI} \\
\text { Affected }^{\star}\end{array}$ & Description of Change \\
\hline New cars & 1967 & 4.70 & $\begin{array}{l}\text { Quality adjustments based on } \\
\text { estimates of manufacturer cost } \\
\text { of new characteristics }\end{array}$ \\
\hline Used cars & 1987 & 1.90 & $\begin{array}{l}\text { Same quality adjustments as for new cars, } \\
\text { with a three-year lag }\end{array}$ \\
\hline Housing & 1989 & 30.20 & $\begin{array}{l}\text { Adjustments for central air-conditioning } \\
\text { and for number of rooms }\end{array}$ \\
\hline Some apparel & 1991 & 2.20 & Hedonics \\
\hline Generic drugs & 1995 & .90 & $\begin{array}{l}\text { Treated as lower price rather than } \\
\text { lower quality relative to branded drugs }\end{array}$ \\
\hline Hospital services & 1997 & 1.40 & $\begin{array}{l}\text { Pricing specific treatments rather than } \\
\text { doctor visits and hospital days }\end{array}$ \\
\hline PCs and peripherals & 1998 & .08 & Hedonics \\
\hline Sample rotation & 1998 & 69.80 & $\begin{array}{l}\text { Every four years rather than every five; } \\
\text { rotating items rather than areas }\end{array}$ \\
\hline TVs & 1999 & .16 & Hedonics \\
\hline Lower-level weights & 1999 & 61.00 & $\begin{array}{l}\text { Fixed nominal shares (geometric mean) } \\
\text { rather than fixed quantities (arithmetic mean) }\end{array}$ \\
\hline $\begin{array}{l}\text { Microwaves, refrigerators, } \\
\text { freezers, clothes washers } \\
\text { and dryers }\end{array}$ & 2000 & .15 & Hedonics \\
\hline Upper-level weights & 2002 & 100.00 & $\begin{array}{l}\text { Updating every two years rather than } \\
\text { less frequently }\end{array}$ \\
\hline
\end{tabular}

"These percentages are based on the December $2000 \mathrm{CPI}$

Source: U.S. Department of Labor, Bureau of Labor Statistics

to-eat or take-out foods ( 83 percent). Third, sales may be lower per new item than for the average item. All of these suggest that variety may have grown more slowly than the number of supermarket items.

An easier task is to ask what has happened to spending on categories that have stayed roughly the same in terms of their quality and variety compared to categories with growing quality and variety. In Bils and Klenow 2001a, we call the former static goods and the latter dynamic goods. A natural way to divide goods into these two classes is according to their noncomparable substitution rate. Based on a cutoff of 0.20 percent per month or less, the following categories qualify as static (in order of increasing noncomparable substitution rates): postage, laundry and dry cleaning, vehicle tolls, cigarettes, fresh fruit, fresh vegetables, telephone charges (other than cellular), taxi fares, intercity train and bus fares, haircuts and barber/ beauty shops, electricity, utility natural gas, appliance re- 
Table 7

\section{A Shift to More Current CPI Weights}

Years of Consumer Expenditure Survey (CES)

That Determine Upper-Level CPI Weights

\begin{tabular}{ccccc}
\hline \multicolumn{2}{c}{ CPI Years } & & \multicolumn{2}{c}{ CES Years } \\
\cline { 5 - 5 } From & To & & From & To \\
\hline 1976 & 1986 & & 1972 & 1973 \\
1987 & 1997 & & 1982 & 1984 \\
1998 & 2001 & & 1993 & 1995 \\
2002 & 2003 & & 1999 & 2000 \\
2004 & 2005 & & 2001 & 2002 \\
2006 & 2007 & & 2003 & 2004 \\
\hline
\end{tabular}

Source: U.S. Department of Labor, Bureau of Labor Statistics

pair, fresh milk, coal and fuel oil, fresh poultry, intracity mass transit, watch and jewelry repair, moving and storage, and fresh pork chops. These categories have an expenditure-weighted average noncomparable substitution rate of only 0.11 percent per month, compared to 1.63 percent for the rest of consumption.

Chart 2 shows that the share of consumer spending on static categories fell almost continuously from 15 percent in 1960 to 8 percent in 2000 . Spending on dynamic goods grew 1.83 percentage points per year faster than spending on static goods over this period. As the chart shows, the same pattern appears if tobacco spending is moved from the static category to the dynamic category (on the grounds that new health information reduced the appeal of these products). ${ }^{15}$ In Bils and Klenow 2001a, we find that no more than 0.3 of a percentage point of the annual shift toward dynamic categories can be accounted for by changes in prices, income, and demographics. The residual 1.53 percentage point annual shift presumably reflects rising quality and variety within dynamic categories. ${ }^{16}$ If so, then the second term in equation (2) is $\lambda \times 1.53 \times$ (the share of dynamic categories in total consumer spending). This averages out to approximately $\lambda \times 1.33$ over $1960-2000$. What is a reasonable value for $\lambda$, the gain from new goods? Estimates of the substitutability between different varieties
Table 8

The Impact of Selected New Goods on Consumer Spending

Spending Share*

$1980 \quad 2000$

As \% of All Spending on Recreation

$\begin{array}{lrr}\text { Television Sets } & 4.9 & 3.5 \\ \text { Cable Television Service } & 1.8 & 5.6 \\ \text { All Television } & 6.7 & 9.1 \\ & & \\ \text { Movies } & 1.9 & 1.2 \\ \text { VCRs and Movie Rentals } & 1.0 & 3.5 \\ \text { Movies, VCRs, and Rentals } & 2.9 & 4.7 \\ \text { Audio and Video (except computers) } & 14.9 & 10.7 \\ \text { Computers } & .1 & 6.2 \\ \text { All Audio and Video } & 15.0 & 16.9\end{array}$

As \% of All Spending on Services

$\begin{array}{lrr}\text { Telephone Charges (except cellular) } & 3.2 & 2.4 \\ \text { Cellular Telephone Charges } & .0 & .9 \\ \text { All Telephone Charges } & 3.2 & 3.3\end{array}$

"The underlying data are nominal consumer expenditures from the U.S. national income and product accounts. Recreation = spending on recreation and on audio and video products; computers = spending on hardware, software, and internet connections: telephone = charges for local, long distance, and cellular services.

Source: U.S. Department of Commerce, Bureau of Economic Analysis

and qualities vary from 2 to 10 . (See Tellis 1988, Pindyck and Rubinfeld 1992, Hausman 1997, and Barsky et al. 2001 for estimates.) Taking the upper bound of this range yields a conservative value for $\lambda$ of 1.11 . This would imply a markup of price over marginal cost of 11 percent. Using this value, one gets $\lambda \times 1.33=1.48$. If the 2.44 percent per

\footnotetext{
${ }^{15}$ Similar results obtain with a cutoff substitution rate of 0.1 percent or 0.3 percent as with 0.2 percent.

${ }^{16}$ In Bills and Klenow 2001a, we net out the effects of changes in income, prices of dynamic vs. static goods, and demographics to arrive at

$\% \Delta($ Dynamic Spending $)-\% \Delta($ Static Spending $)=\% \Delta Q+\% \Delta N$
}

where $\% \Delta Q$ and $\% \Delta N$ are the growth rates of quality and variety in dynamic categories. The growth rates of quality and variety in static categories are assumed to be zero. 
year BEA measure of real per capita consumption growth fully captures variety and quality growth, then this exercise suggests that around 60 percent of growth (1.48 of the 2.44 ) took the form of rising variety and quality, with the rest coming from rising quantity. If, instead, the BEA understated real consumption growth by 0.9 of a percentage point per year during 1960-2000, as estimated by the Boskin Commission, then true consumption growth was 3.34 percent per year, about 44 percent of which consisted of rising variety and quality (1.48 of the 3.34 ).

The above exercise is similar in spirit to those of Nakamura (1997), Costa (2001), and Hamilton (2001). Nakamura breaks consumption into nine categories and finds that trends in their shares continued their 1959-74 pace over 1974-94. If growth is what drives changes in shares, Nakamura reasons, then the true growth rate did not fall as measured growth did. Costa compares changes in spending on food and entertainment to the spending patterns of richer and poorer households at several points in the 20th century. In the 1970 s and 1980 s, the decline in food's share and the increase in entertainment's share both suggest that people became richer faster than implied by BEA statistics. Hamilton carries out a similar exercise for food's share and reaches the same conclusion as Costa does.

In Bils and Klenow 2001b, we take a different route to infer the role of quality growth in overall consumption growth. Using CES spending for 1980-96, we estimate quality Engel curves for 66 durable goods. ${ }^{17}$ In contrast to an overall Engel curve tracing out a household's expenditures on a good against the household's overall consumption, our quality Engel curve traces out the unit price paid for a good against overall consumption. (The overall Engel curve is then a product of our quality Engel curve and a quantity Engel curve tracing out the number of units bought against overall consumption.) Our premise is that, across households at a point in time, those paying higher unit prices are buying higher quality goods. Not surprisingly, richer households bought higher priced goods, resulting in positively sloped quality Engel curves for all 66 goods. Across the 66 goods, the quality portion of the overall Engel curve ranges from 23 percent for microwaves to 74 percent for trucks and averages 56 percent (weighting the goods by their importance in the CPI).

Over time, as real income rises, people should be climbing up their quality and quantity Engel curves. If they do so at the rate predicted by spending patterns across households, then 56 percent of growth in consumption of the 66 durables takes the form of quality growth.
Chart 2

\section{Consumer Spending on Static Goods}

As $\%$ of All Consumer Spending, Annually, 1960-2000

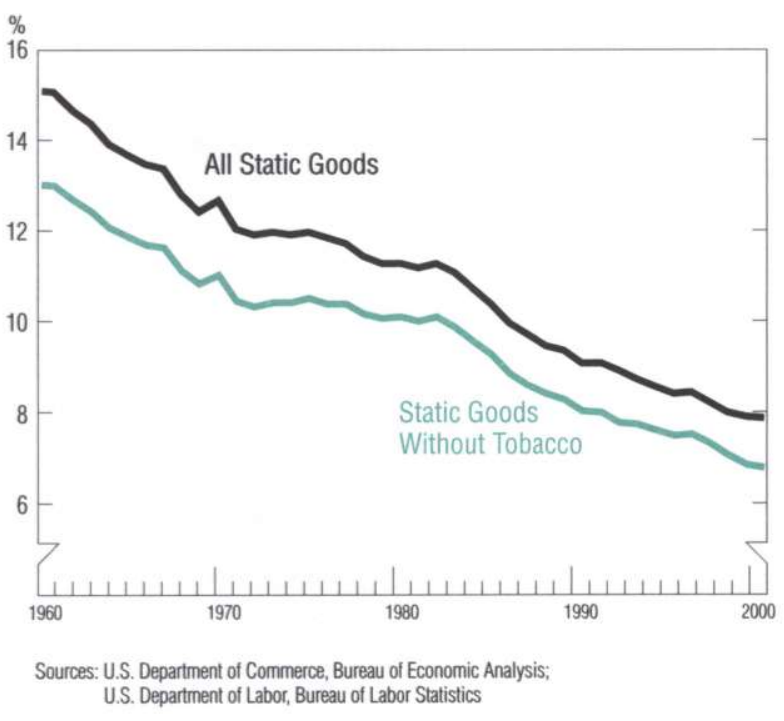

Two caveats apply to this calculation. First, the relative price and availability of various qualities can change in ways that reinforce or limit the Engel curve effects. Second, our quality slope estimates could be biased upward or downward. They might be biased upward if richer households tend to pay higher markups for a given quality product. For cars, at least, this does not appear to be the case. Goldberg (1996) finds no correlation between the price a household pays for a particular car model and the household's income, financial assets, education, or occupation. Moreover, the markups would have to vary a lot. If household $A$ has twice the overall consumption of household $B$, then household $A$ typically pays about 76 percent more for a consumer durable. This is many times larger than most estimates of markups. A potential bias going the other way is that part of the quality Engel curve could be misattributed to the quantity Engel curve if richer households replace their durables more frequently. If richer households have less-depreciated durables on average,

\footnotetext{
${ }^{17}$ The sample of 66 goods is based on availability of unit price data in the CES. These 66 goods constitute about 80 percent of household spending on durables and about 12 percent of overall consumption.
} 
this would not be captured in the unit price they pay and, therefore, would not show up in our quality slopes.

Bils and I (2001b) also present evidence that our crosssectional quality slopes help predict the speed of quality upgrading over time. Just as if households ascend quality Engel curves over time, the average price paid rose faster from 1980 to 1996 for goods with steeper quality Engel curves. BLS prices also increased more quickly for goods with steeper quality Engel curves, suggesting the BLS did not fully net out the impact of quality upgrading on prices paid during this period. We estimate quality growth of about 3.7 percent per year for the 66 goods. We estimate that BLS quality adjustments captured about 40 percent of this upgrading, with roughly 60 percent, or 2.2 percent per year, showing up as inflation rather than real growth. Even allowing for sampling error, our estimates imply that at least one-third of quality growth showed up as inflation, biasing consumer durables inflation upward by at least 0.8 of a percent per year over 1980-96. For this subset of goods, our findings bolster the Boskin Commission's contention that BLS quality adjustments miss a significant fraction of quality growth.

\section{Concluding Comments}

According to official statistics, U.S. real consumption per capita grew 2.4 percent per year between 1960 and 2000. The findings of the Boskin Commission (U.S. Congress 1996) suggest the true growth rate was closer to 3.3 percent per year, with two-thirds of this difference due to variety and quality growth. Methodological changes undertaken by the BLS since 1996 are expected to boost measured growth of real consumption by about 0.4 of a percentage point per year going forward (relative to what it would otherwise be, not relative to past growth). Based on current methodology, Lebow and Rudd (2001) expect real consumption growth to be understated by about 0.5 of a percentage point per year going forward, primarily because growth in variety and quality remains difficult to fully capture.

I offer two minor recommendations for further improving BLS methodology. One is that the BLS begin tabulating the difference between inflation in average unit prices and inflation in the CPI. This gap reflects BLS quality adjustments, including passive adjustments when consumers shift toward higher quality products and active adjustments around forced item substitutions. To obtain unit prices, the BLS could supplement CPI price quotes with unit prices from household surveys and from scanner data. The BLS could use this summary measure of quality ad- justments to estimate the contribution of quality growth to overall consumption growth. Another suggestion is that the BLS begin estimating variety growth using the difference between the turnover rate at regular sample rotations and the rate of forced item substitutions. This would provide insight into the contribution of variety growth to overall consumption growth and, combined with estimates of the substitutability of different varieties, would afford an estimate of consumer surplus from the arrival of new varieties. 


\section{References}

Barsky, Robert; Bergen, Mark; Dutta, Shantanu; and Levy, Daniel. 2001. What can the price gap between branded and private label products tell us about markups? Working Paper 8426. National Bureau of Economic Research.

Berndt, Ernst R.; Pindyck, Robert S.; and Azoulay, Pierre. 2000. Consumption externalities and diffusion in pharmaceutical markets: Antiulcer drugs. Working Paper 7772. National Bureau of Economic Research.

Bils, Mark, and Klenow, Peter J. 2001a. The acceleration in variety growth. American Economic Review 91 (May): 274-80.

2001b. Quantifying quality growth. American Economic Review 91 (September): 1006-30.

Costa, Dora L. 2001. Estimating real income in the United States from 1888 to 1994 Correcting CPI bias using Engel curves. Journal of Political Economy 109 (December): $1288-1310$.

Cutler, David M.; McClellan, Mark; Newhouse, Joseph P.; and Remler, Dahlia. 1998. Are medical prices declining? Evidence from heart attack treatments. Quarterly Journal of Economics 113 (November): 991-1024.

Food Marketing Institute. 2000. New products and services. Obtained 4/01 at http:// www.fmi.org/.

Goldberg, Pinelopi Koujianou. 1996. Dealer price discrimination in new car purchases: Evidence from the consumer expenditure survey. Journal of Political Economy 104 (June): 622-54.

Goolsbee, Austan, and Klenow, Peter J. 2002. Evidence on leaming and network externalities in the diffusion of home computers. Journal of Law and Economics 45 (October): 317-44.

Gordon, Robert J. 2000. The Boskin Commission report and its aftermath. Working Paper 7759. National Bureau of Economic Research.

Gort, Michael, and Klepper, Steven. 1982. Time paths in the diffusion of product innovations. Economic Joumal 92 (September): 630-53.

Hamilton, Bruce W. 2001. Using Engel's law to estimate CPI bias. American Economic Review 91 (June): 619-30.

Hausman, Jerry A. 1997. Valuation of new goods under perfect and imperfect competition. In The economics of new goods, ed. Timothy F. Bresnahan and Robert J. Gordon, pp. 209-37. National Bureau of Economic Research Studies in Income and Wealth, Vol. 58. Chicago: University of Chicago Press.

1999. Cellular telephone, new products, and the CPI. Journal of Business and Economic Statistics 17 (April): 188-94.

Irwin, Douglas A., and Klenow, Peter J. 1994. Learning-by-doing spillovers in the semiconductor industry. Journal of Political Economy 102 (December): 12001227.

Lebow, David E.; Roberts, John M.; and Stockton, David J. 1994. Monetary policy and "the price level." Manuscript. Board of Governors of the Federal Reserve System.
Lebow, David E., and Rudd, Jeremy B. 2001. Measurement error in the consumer price index: Where do we stand? Finance and Economics Discussion Series Paper 2001-61. Board of Governors of the Federal Reserve System.

Moulton, Brent R., and Moses, Karin E. 1997. Addressing the quality change issue in the consumer price index. Brookings Papers on Economic Activity 1 (1): $305-$ 49.

Nakamura, Leonard. 1997. Is the U.S. economy really growing too slowly? Maybe we're measuring growth wrong. Federal Reserve Bank of Philadelphia Business Review, March/April: 3-14.

Petrin, Amil. 2002. Quantifying the benefits of new products: The case of the minivan. Journal of Political Economy 110 (August): 705-29.

Pindyck, Robert S., and Rubinfeld, Daniel L. 1992. Microeconomics. 2nd ed. New York: Macmillan.

Rohlfs, Jeffrey H. 2001. Bandwagon effects in high-technology industries. Cambridge, Mass.: MIT Press.

Shapiro, Irving; Shapiro, Matthew D.; and Wilcox, David W. 1999. Quality improvement in health care: A framework for price and output measurement. Working Paper 6971. National Bureau of Economic Research.

Shapiro, Matthew D., and Wilcox, David W. 1996. Mismeasurement in the consumer price index: An evaluation. NBER Macroeconomics Annual 1996, ed. Ben S. Bernanke and Julio Rotemberg, Vol. 11, pp. 93-142. Cambridge, Mass.: MIT Press.

1997. Alternative strategies for aggregating prices in the CPI. Federal Reserve Bank of St. Louis Review 79 (May/June): 113-25.

Tellis, Gerard J. 1988. The price elasticity of selective demand: A meta-analysis of econometric models of sales. Journal of Marketing Research 25 (November): $331-41$.

U.S. Congress. 1996. Senate. Toward a more accurate measure of the cost of living. Final report to the Senate Finance Committee from the Advisory Commission to Study the Consumer Price Index. 104th Cong., 2nd sess., S.Prt. 104-072. Obtained 1/03 at http://www.ssa.gov/history/reports/boskinrpt.html.

2000. General Accounting Office. Consumer price index: Update of Boskin Commission's estimate of bias. Report to the Ranking Minority Member, Senate Finance Committee. GAO/GGD-00-50. Washington, D.C.: U.S. General Accounting Office. Obtained 1/03 at http://www.access.gpo.gov/su_docs/aces/ aces 160. shtml.

U.S. Department of Commerce. 2001. Bureau of Economic Analysis. A guide to the NIPA's. Methodology, national income and product accounts of the United States, 1929-97. Obtained 1/03 at http://www.bea.gov/bea/an/nipaguid.pdf.

U.S. Department of Labor. 1997. Bureau of Labor Statistics. BLS handbook of methods. BLS Bulletin 2490. Washington, D.C.: U.S. Government Printing Office. Obtained 1/03 at http://www.bls.gov/opub/hom/. 